\title{
The Impact of Cumulus Parameterization on Rainfall Simulations over East Africa
}

\author{
G. Otieno ${ }^{1}$, J. Mutemi ${ }^{1}$, F. Opijah ${ }^{1}$, L. Ogallo ${ }^{2}$, G. Artan ${ }^{2}$, H. Omondi ${ }^{2}$ \\ ${ }^{1}$ University of Nairobi, Department of Meteorology, Nairobi, Kenya \\ ${ }^{2}$ IGAD Climate Prediction and Application Centre, Nairobi, Kenya \\ Email: ^gotieno@2000@gmail.com
}

How to cite this paper: Otieno, G., Mutemi, J., Opijah, F., Ogallo, L., Artan, G. and Omondi, H. (2018) The Impact of Cumulus Parameterization on Rainfall Simulations over East Africa. Atmospheric and Climate Sciences, 8, 355-371.

https://doi.org/10.4236/acs.2018.83024

Received: June 7, 2018

Accepted: July 28, 2018

Published: July 31, 2018

Copyright (๑) 2018 by authors and Scientific Research Publishing Inc. This work is licensed under the Creative Commons Attribution International License (CC BY 4.0).

http://creativecommons.org/licenses/by/4.0/

\begin{abstract}
The study explored the ability of four cumulus parameterization schemes (CPSs) from Weather and Research Forecasting model (WRF) to simulate mean rainfall patterns, number of rainy days (NRD) and vertically integrated moisture flux (VIMF) during the composite of wet years for the core rainfall seasons of March-April-May (MAM; 1989, 1998 and 2012) and October-November-December (OND; 1997, 2006 and 2015) seasons. The CPSs used were Kain-Fritsch (KF), Kain-Fritsch with a moisture-advection based trigger function (KFT), Grell Dévényi (GRELL) and Betts Miller Janjic (BML). The simulations by the GRELL and KF schemes were clearly separated by the dry and wet rainfall gradient in the simulations. For example, the GRELL scheme rainfall simulations were drier over the eastern parts of the region better. The KF and KFT schemes generated wetter rainfall conditions mainly confined to the western parts of the region. The BML scheme simulations were not consistent with the observations. The western and eastern parts of the region were characterized by more and fewer NRD, in both the KF and GRELL schemes. The root mean square error (RMSE) and spatial correlation by KF scheme was $2 \mathrm{~mm}$ /day and 0.6. The GRELL scheme however simulated low correlation of 0.45 and RMSE of about $3.0 \mathrm{~mm}$ /day over most of the sub-domains. The moisture convergence biases were found to be larger continentally and parts of the nearby Indian Ocean. The persisting rainfall biases constituting of too wet and dry conditions were associated with the KF and GRELL cumulus schemes. The findings from the current study are very fundamental for the improvement of numerical weather prediction (NWP) tools and cumulus modification processes over the region. The accurate and higher skill rainfall forecasts would provide early warning information for disaster risk reduction and the related risks on the livelihoods.
\end{abstract}




\section{Keywords}

Rainfall Characteristics, Cumulus Schemes, East Africa

\section{Introduction}

The contrasts between land and water bodies, together with the undulating topography, interact with the Inter-Tropical Convergence Zone (ITCZ) as it traverses the East Africa (EA) region, resulting into complex but interesting spatial and temporal variations of rainfall over the region. The unique characteristics of the region imply that the spatial and temporal distribution of rainfall develops smaller-scale features that are not generally well represented by coarse-resolution general circulation models (GCMs) [1]. The GCMs are considered as potent tools capable of simulating large-scale circulation and the global climate, but are inadequate in providing detailed regional-scale features of the climate, for accurate rainfall simulation [2] [3]. The dynamic downscaling is an acceptable approach globally to bridge the gap between the regional climate information and the GCM. It is an accepted practice to use the regional climate models (RCMs) for downscaling global models, because of the more comprehensive representation of the important physical processes at a finer resolution [4] [5].

Over the EA region, there are still enormous challenge in applicability of the RCMs to correctly represent the rainfall characteristics arising from the complexity of representing the physical processes of precipitation, including cumulus convection, planetary boundary-layer turbulence, cloud microphysics and radiative forcing [6]. The cumulus convection plays a significant role in regulating the pattern and temporal variation in precipitation in RCMs, especially within the tropics. The WRF model has numerous cumulus schemes that are extensible being used by the scientific community without proper sensitivity test over the region.

Regional studies including [7]-[13] have evaluated the performance of RCMs with much success achieved in reproducing rainfall due large-scale systems like the ITCZ. Despite all these efforts, little have been achieved on local and meso-scale systems that dominate the seasonal rainfall over the region [14] [15] [16].

Studies by [17] [18] pointed out that poor representation of the cumulus parameterization schemes in the present day RCMs is partly the major cause of the low quality in the climate forecasts. The cumulus schemes are of primary importance for rainfall within the tropics [6] [19] [20] [21] and therefore evaluating their impact to various rainfall characteristics becomes fundamental step towards improving the NWP approach. The growing socioeconomic impact of rainfall in the region, with its rain-fed agriculture dictates that the statistical-dynamical approaches should be fostered in parallel to improve the predicta- 
bility of rainfall in this region.

The aim of the current study was therefore to investigate the impact of four different cumulus schemes on the simulation the rainfall characteristics over EA region using the WRF model for the composited wet years of 1989, 1997, 1998, 2006, 2012 and 2015. The reanalysis fields from ERA-Interim was used to quantify the possible causes of any deficiency in downscaling by the WRF model since it is considered to provide "perfect" lateral boundary conditions [22]. The paper was organized as follows: Section 2 presented model description and experimental design, data and methods; Section 3 presented results from rainfall simulations and the associated biases, and Section 4 contained summary and conclusion.

\section{Study Domain, Model Description and Experimental Design}

\subsection{Study Domain}

The East Africa region was subdivided into four sub-domains. Figure $1 \mathrm{com}-$ prises the Northern East Africa (NEA) between $35.5^{\circ} \mathrm{E}$ to $43.5^{\circ} \mathrm{E}$ and $1.5^{\circ} \mathrm{S}$ $3.5^{\circ} \mathrm{N}$, Southern East Africa (SEA) between $32^{\circ} \mathrm{E}$ to $37.5^{\circ} \mathrm{E}$, and $8.5^{\circ} \mathrm{S}$ to $4.5^{\circ} \mathrm{S}$,

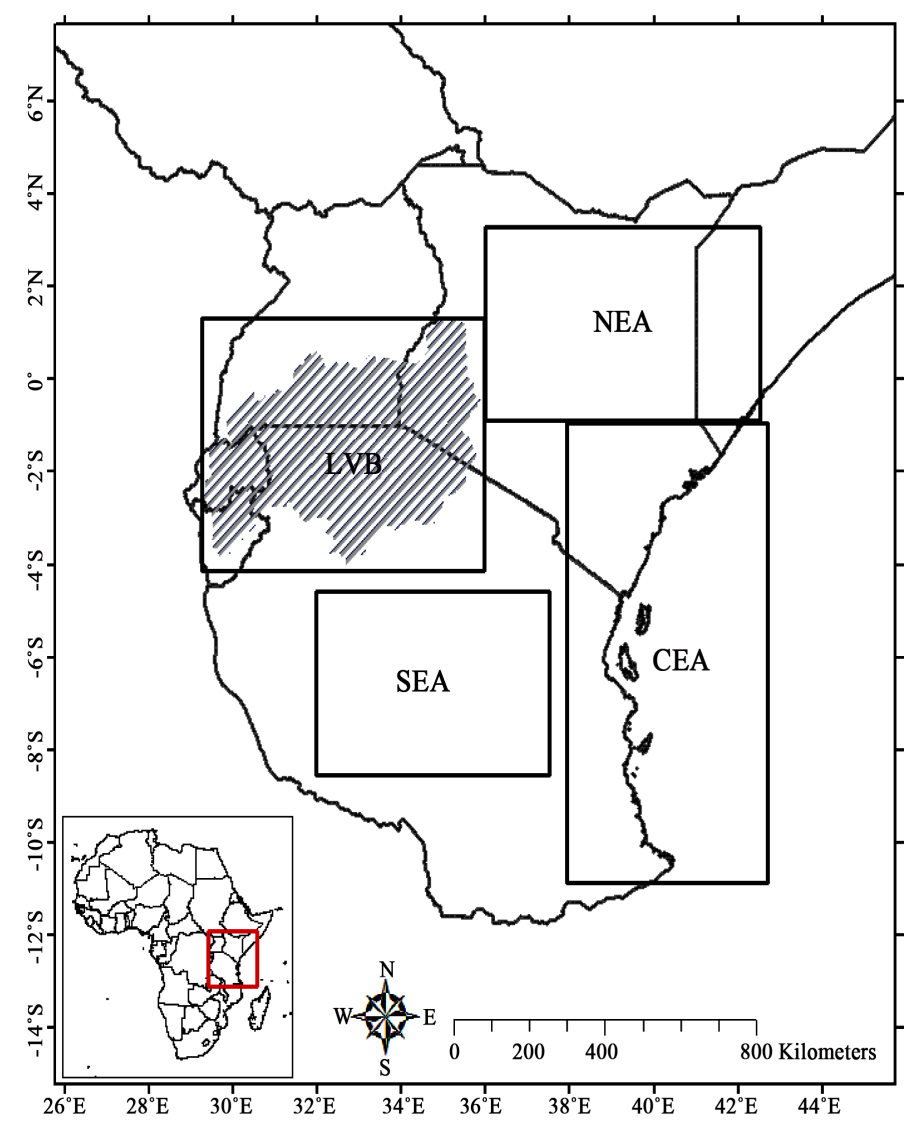

Figure 1. Study Area with four sub-domains SEA, NEA, LVB and CEA utilized for analysis in this study during MAM and OND seasons. The shaded area shows the extent covered by the Lake Victoria basin. 
Lake Victoria Basin (LVB) between $29^{\circ} \mathrm{E}-36.2^{\circ} \mathrm{E}$ and $1.5^{\circ} \mathrm{N}$ and $4^{\circ} \mathrm{S}$ and Coastal East Africa (CEA) between $38^{\circ} \mathrm{E}-42^{\circ} \mathrm{E}$ and $11^{\circ} \mathrm{S}-1^{\circ} \mathrm{S}$ utilized for analysis during MAM and OND rainfall seasons. These sub-domains were based on the main rainfall mechanisms and forcing whose interplay controls the weather, including the atmospheric circulation, influences of Indian and Atlantic Ocean thermal reservoirs, and regional and local factors [23] [24] [25].

\subsection{Model Description}

The WRF model has been accepted worldwide as a research and forecasting tool. The model is largely preferred by modeling community for numerical weather studies [9] [26] [27]. It has an ARW dynamics solver that integrates the compressible and non-hydrostatic Euler equations. The equations are formulated using a terrain-following mass conservation vertical coordinate [28] [29]. The ERA-Interim reanalysis from European Centre for Medium-Range Weather Forecasts (ECMWF) [30] was used to provide 6-hourly initial and lateral boundary conditions for large scale forcing fields in WRF model. The lateral boundary forcing fields included geopotential height, air temperature, specific humidity and horizontal winds. The sea surface temperatures (SSTs) from national oceanic and atmospheric administration (NOAA) were used to provide lower boundary forcing, updated 6-hourly in the model. The topographical information at 10 minutes horizontal resolution was obtained from United State Geological Survey (USGS). Throughout the domain WRF was coupled with the 4-layer NOAH land surface model [31]. The land use land cover (LULC) data was derived from United States Geological Survey (USGS) database, which describes a 24 category land-use index based on climatological averages.

\subsection{The Experimental Design}

Four different simulations were performed for the widespread wet years using four alternative cumulus schemes in the WRF model configured at $0.3^{\circ}$ resolution $(\sim 36 \mathrm{~km})$. The simulations were carried out over the domain $0^{\circ} \mathrm{E}-75^{\circ} \mathrm{E}$ and $20^{\circ} \mathrm{S}-27^{\circ} \mathrm{N}$ (190 by 145 gridpoints) as recommend by [10] [15], but with few modifications constraining the model domain over Congo airmass, Indian Ocean and Arabian highland which are regions that greatly impact rainfall over the domain [32]. The domain encloses moisture sources like the Congo region, Indian Ocean and inland water bodies like Lake Victoria that are key in modulating the internal dynamics of the regional climate. This criterion and choice of domain have been extensively used by [33] [34] [35].

The integrations were initialized on the 1st day of the month preceding the season. The integration timestep was 3 minutes and model output data archived every 6 hour from the first day of the simulation. The first month of the simulations were used as spin-up to let the model adjust to atmospheric initial conditions.

The Planetary Boundary Layer (PBL) from Yonsei University [36], Microphysics (MP) of WRF Single Moment 6-class 6 (WSM6) [37] and Rapid Radia- 
tive Transfer Model (RRTMG) for short and long wave radiation [38] were used alongside the four CPSs. The four CPS were selected on the basis of their widespread use in numerical models and the representativeness of different closure assumptions and scale considerations. The KF scheme is a mass flux closure assumption and uses a 1dimensional updraft-downdraft couplet, with no lateral entrainment [39] [40] [41] [42].

The GRELL [43] [44] is based on an updraft and downdraft pair in steady state circulations with no direct mixing between the environment and convective clouds except at the top and bottom of the circulations. The mass flux in the updraft and downdraft is assumed constant with height and no entrainment or detrainment occurs along the cloud edges. The originating levels of the updraft and downdraft are given by the levels of maximum and minimum moist static energy, respectively. The BML [19] [45] on the other hand, is a lagged convective adjustment scheme. It adjusts the model's thermal and moisture structures toward specified reference profiles that reflect the quasi-equilibrium state established by deep convection. The experiment one differed from two in the moisture trigger function introduced [41].

\subsection{Vertically Integrated Moisture Flux}

The vertically integrated moisture flux (VIMF) is a dynamical quantity in the conservation of water vapor equation. It is a useful quantity to predict rainfall associated with synoptic-scale systems. Equation 1 for atmospheric water budget was used to describe the VIMF.

$$
\partial P W / \partial t+M F D=\bar{E}-\bar{P}
$$

In Equation (1), $E$ is evaporation from the surface; $M F D$ is the vertically integrated moisture divergence between the surface and top atmosphere and $\partial P W / \partial t$ is the temporal variation and precipitable water within air column [45] [46] [47] [48].

This study used the VIMF to establish the capability of the CPSs to simulate rainfall and integrated moisture flux. The observed daily rainfall was obtained from Climate Hazards Group Infrared Precipitation with station data (CHIRPS), [49] at $0.25^{\circ}$ resolutions for model evaluation. The atmospheric fields (i.e., $\mathrm{u}$ and v) wind vectors and specific humidity were drawn from ERA-interim reanalysis [24] [50]. The quantification of the CPS skill was done using RMSE and spatial correlation (SC).

\section{Results and Discussions}

\subsection{Mean Seasonal Rainfall}

Figure 2 shows the differences between the simulations of wet and dry years by the various CPSs. The wet minus dry was done to show the distinction between the CPSs in reproducing the wet and drier years. The GREL and BML clearly tended to be drier over southern parts of Tanzania and Central parts Uganda 


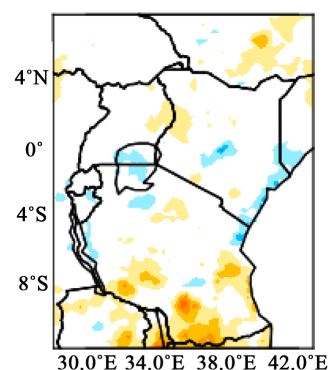

(a)

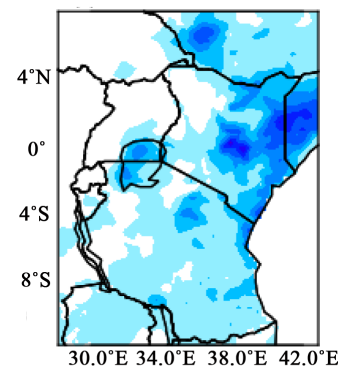

(f)

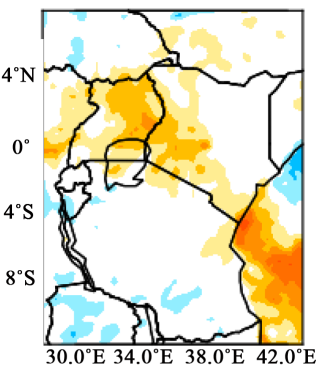

(b)

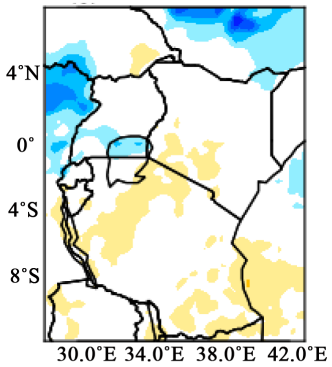

(g)

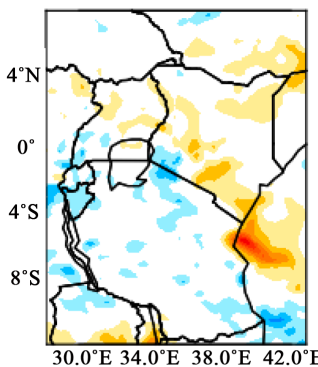

(c)

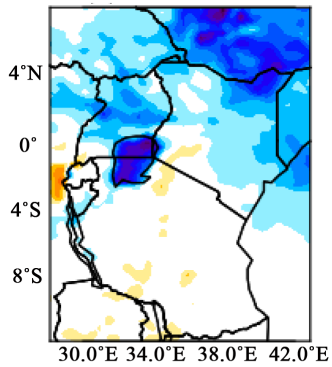

(h)

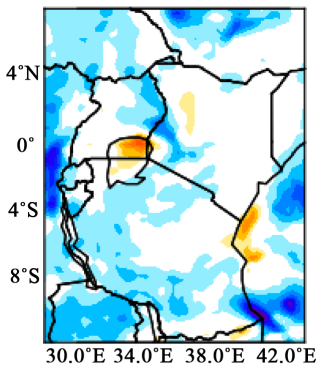

(d)

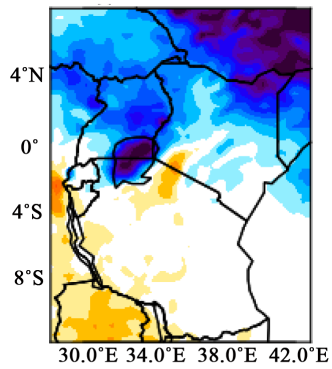

(i)

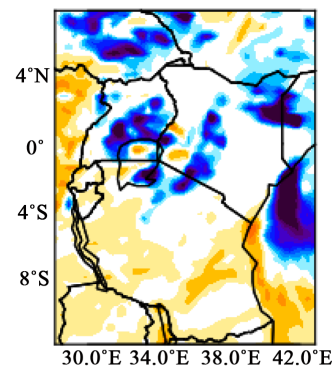

(e)

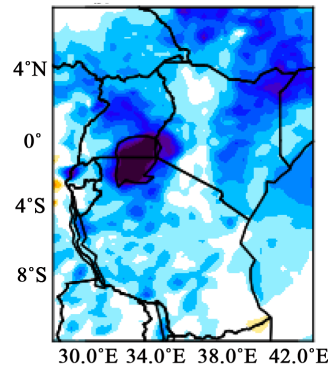

(j)

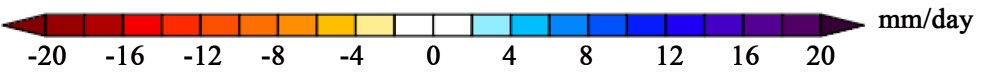

Figure 2. The observed and simulated wet minus dry for CHIRPS, GRELL, BML, KF and KFT CPS. The top and bottom represent the MAM and OND rainfall seasons respectively. (a) CHIRPS; (b) GRELL; (c) BML; (d) KF; (e) KFT; (f) CHIRPS; (g) GRELL; (h) BML; (i) KF; (j) KFT.

and Kenya; these areas coincided with the observations (Figures 2(a)-(c)) during MAM season. The KF scheme was indeed wetter over western parts of region and drier over Eastern parts; the KFT on the other hand reproduces observed rainfall over southern Tanzania but places a wetter bias over Equatorial region (Figure 2(d) and Figure 2(e)). The OND season was correctly reproduced by all the CPSs over northern parts of Equatorial region except for GRELL CPSs that tended to be drier throughout (Figures $2(\mathrm{f})-(\mathrm{j})$ ). These observations denote a characteristic behavior of GRELL schemes tending to be drier and KF/KFT schemes favoring a wetter rainfall conditions. Past studies using the same schemes i.e. [9] [27] [51], had reported similar findings.

\subsection{Simulated Rainy Days}

We further analyzed the performance of these schemes in simulating rainfall in terms of number of rainy days ( $>1 \mathrm{~mm} /$ day). Figure 3 shows the simulated NRD during the MAM and OND rainfall seasons. The BML and GRELL CPSs correctly simulated rainfall above 20 days to the western parts of the equatorial region (Figures 3(a)-(c)). Fewer rainy days were simulated by the schemes on the eastern sides (less than 10 days) during the MAM season by the GRELL scheme. The KF scheme simulated more rainy days over western equatorial region above 30 days. The KFT scheme was most accurate in term of NRD over the western equatorial region and eastern sides compared to the KF scheme (Figure 3(d) and Figure 3(e)). During the OND season, the GRELL simulations were closer 


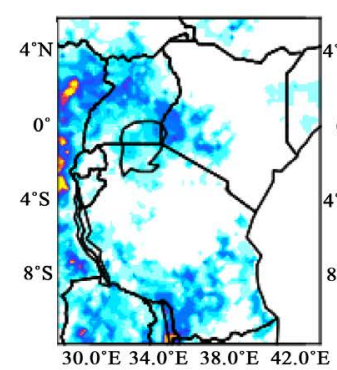

(a)

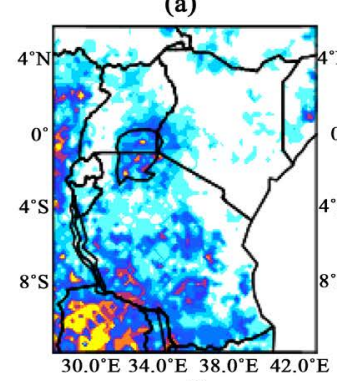

(f)

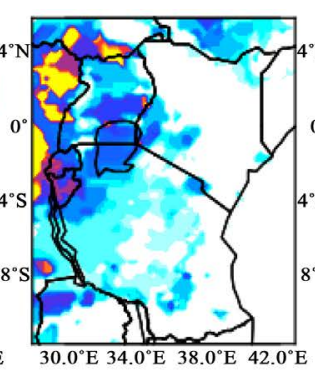

(b)

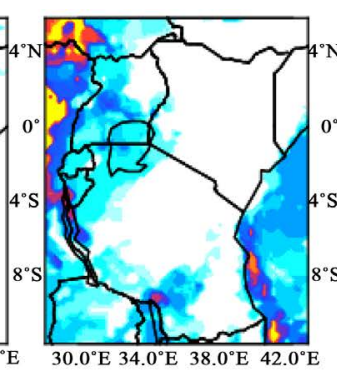

(c)

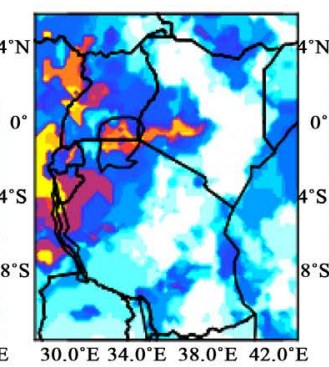

(d)

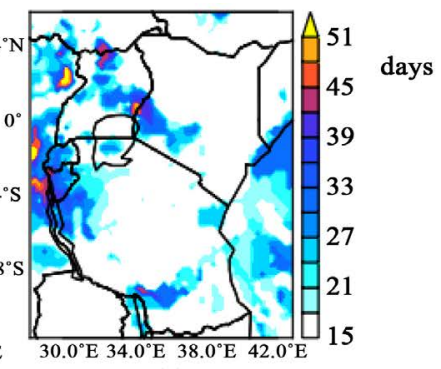

(e)

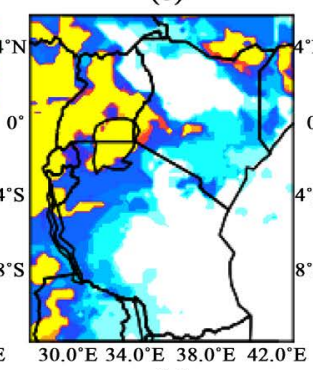

(g)

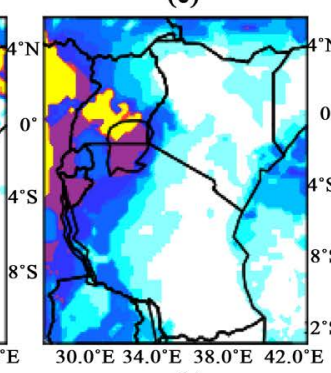

(h)

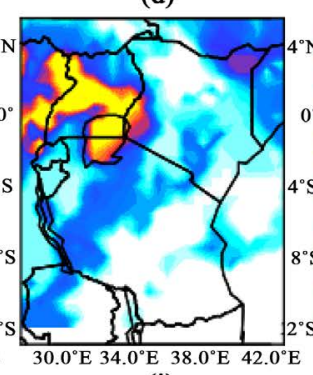

(i)

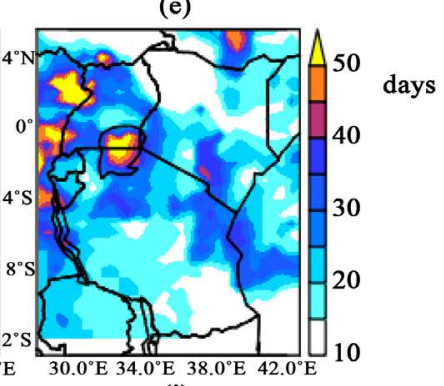

(j)

Figure 3. The observed and simulated NRD (days) by CHIRPS, GRELL, BML, KF and KFT CPS for composite of wet years during MAM (top: 1989, 1998 and 2012) and OND (bottom: 1997, 2006 and 2015). (a) CHIRPS; (b) BML; (c) GRELL; (d) KF; (e) KFT; (f) CHIRPS; (g) BML; (h) GRELL; (i) KF; (j) KFT.

to the observations than the rest of the CPSs over western equatorial region (Figure 3(f) and Figure 3(h)). All the CPSs overestimated the NRD over the western sector of the region. The KF and KFT schemes misplaced rainy days above 50 days over the equatorial sector.

These findings suggest that the wetter rainfall conditions in KF and KFT schemes are related to the more NRD simulated by the CPSs. Similarly, drier rainfall conditions simulated by the GRELL and BML schemes were related to the few NRD. These findings support earlier study by Sun [52]. A more recent study by [51] also found that biases in regional climate models in most cases emanate from many or fewer rainy days simulated the models.

Using moisture based advection function successfully lowered the overestimation of rainfall amount and number of rainy days in the KFT scheme (Figure $3(e)$ and Figure $3(j))$. The results from the current studies corroborates with the recent findings from [52] [53]. These studies convergent found that regional climate models tend to be wetter or drier; an inherent nature related to more or fewer rainy days.

\subsection{Temporal Rainfall Distribution}

The study summarized the skill of the cumulus schemes based on the root mean square error (RMSE), standard deviation (SD) and correlation in Taylor diagram. Also the mean distribution of the schemes was done using box and whisker plots over NEA, SEA, CEA and LVB sub-domains for the composite of wet years. Figure 4 and Figure 5 show the Taylor plots during MAM and OND seasons respectively. 


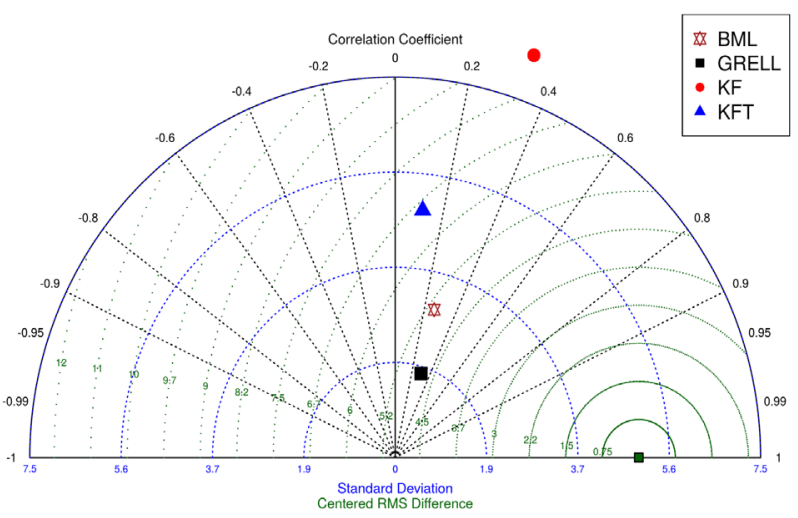

(a)

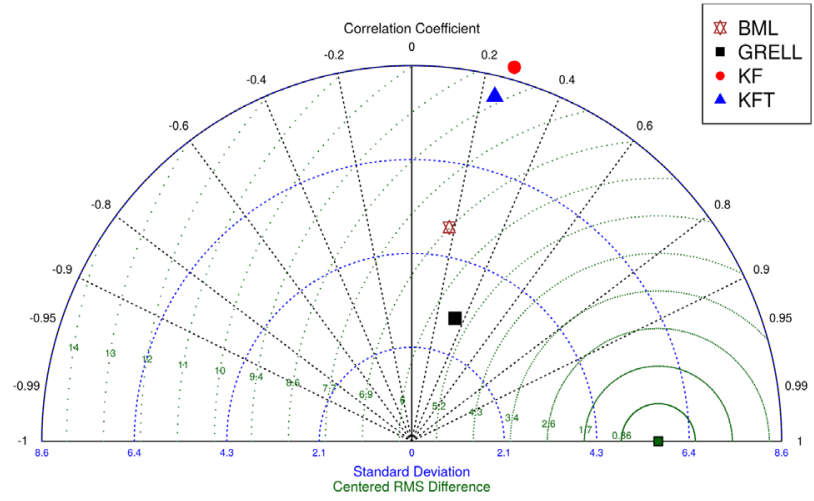

(c)

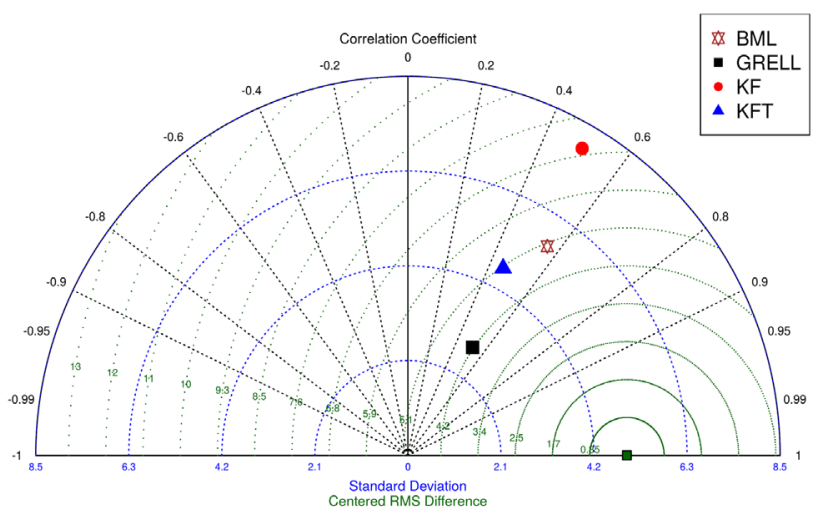

(b)

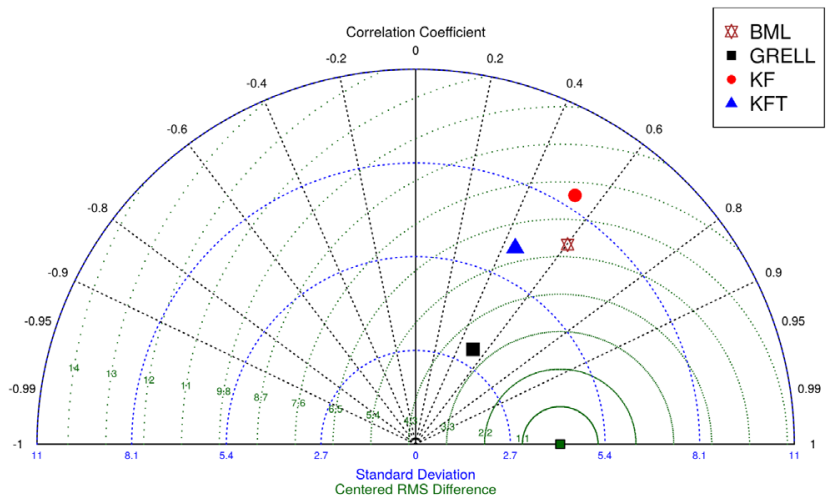

(d)

Figure 4. Taylor diagram displaying statistical comparison of seasonal mean rainfall for BML(brown), GRELL(black), KF(red) and KFT(blue) with observations over (a) NEA; (b) SEA; (c) CEA; (d) LVB sub-domains during the MAM season. The blue and green curves represent standard deviation (SD) and root mean square differences (RMSD) respectively for the composite of wet years.

The cumulus schemes were most skillful over SEA and LVB sub-domains with correlation coefficient between the observations and CHIRPS ranging from 0.4 to 0.6 (Figure 4(b) and Figure 4(d)). The KF, KFT and GRELL schemes correlation values was about 0.5 . For the OND season, the schemes poorly replicated the rainfall systems in all the domains except over SEA and LVB where KFT scheme simulated correlation values of 0.65 and 0.4 respectively (Figure 5(b) and Figure 5(d)).

The simulations over LVB and CEA domains were poor. Smaller RMSE of about $2.3 \mathrm{~mm}$ /day was simulated by the KF and BML schemes over NEA and SEA sub-domains. The KF, KFT and GRELL schemes in most cases had RMSD ranging between 1.5 to $6 \mathrm{~mm} /$ day with standard deviation of 1.5. From the above analyses, we concluded that the KF and KFT schemes were most skillful.

The distribution of the rainfall simulated by the schemes clearly depended on the sub-domain and the scheme. For example, over the CEA region for MAM season (Figure 6), only BML scheme was closest to the observation in terms of mean values. The rest of the CPSs either underestimated or overestimated the mean values. Similar observations were replicated over LVB sub-domain. The 


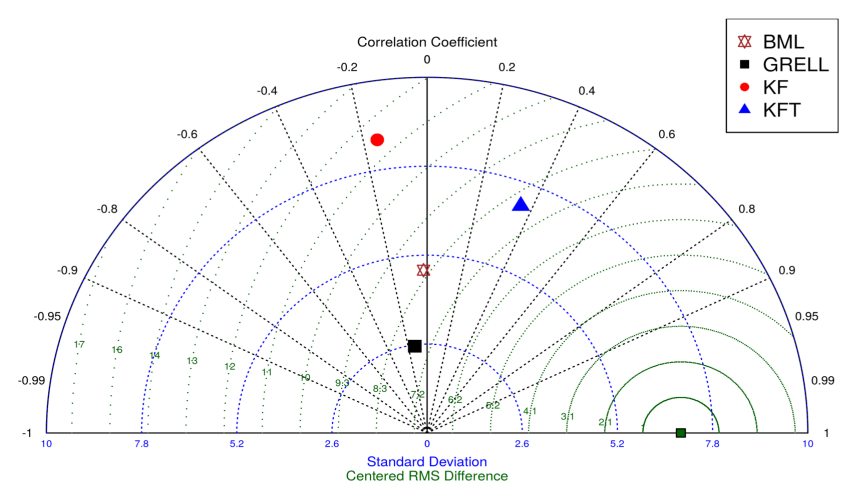

(a)

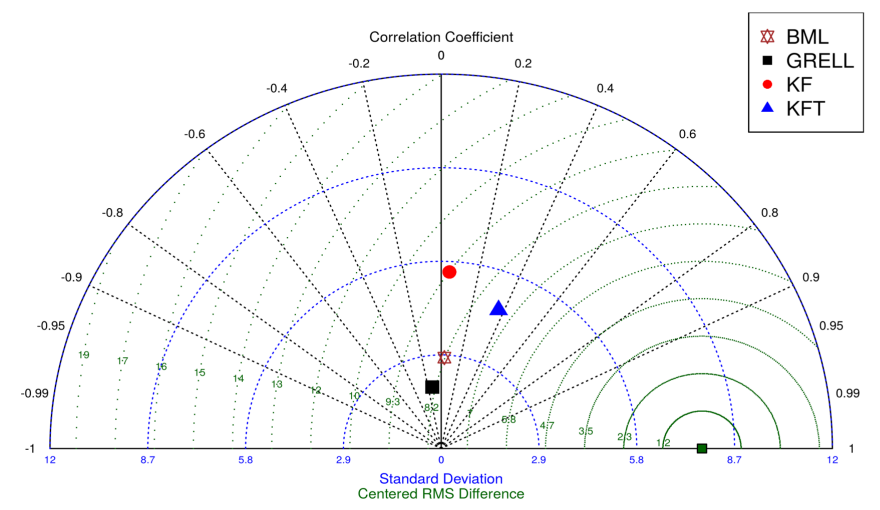

(c)

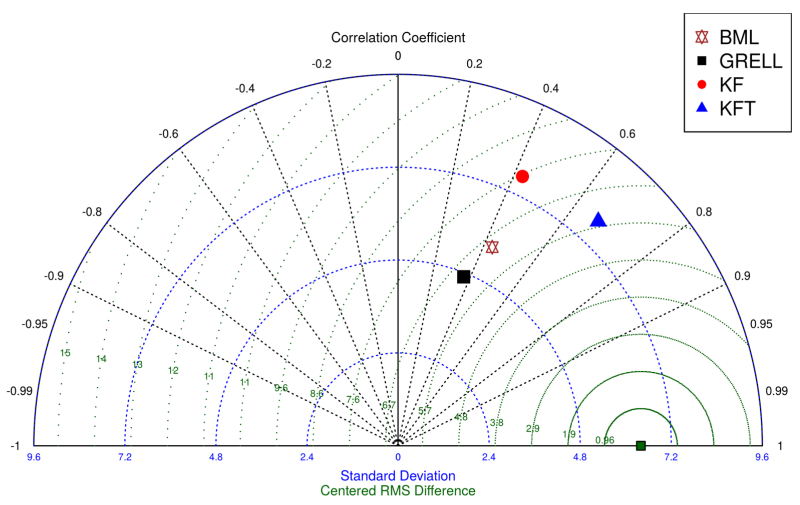

(b)

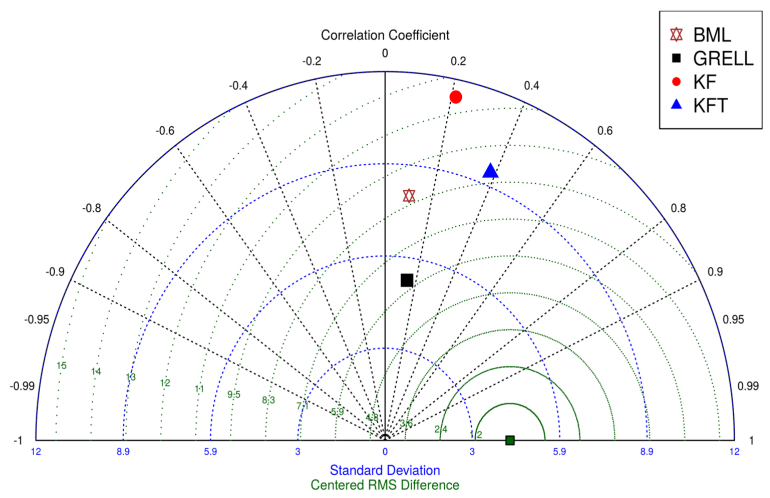

(d)

Figure 5. Same as Figure 4 but for the OND season.

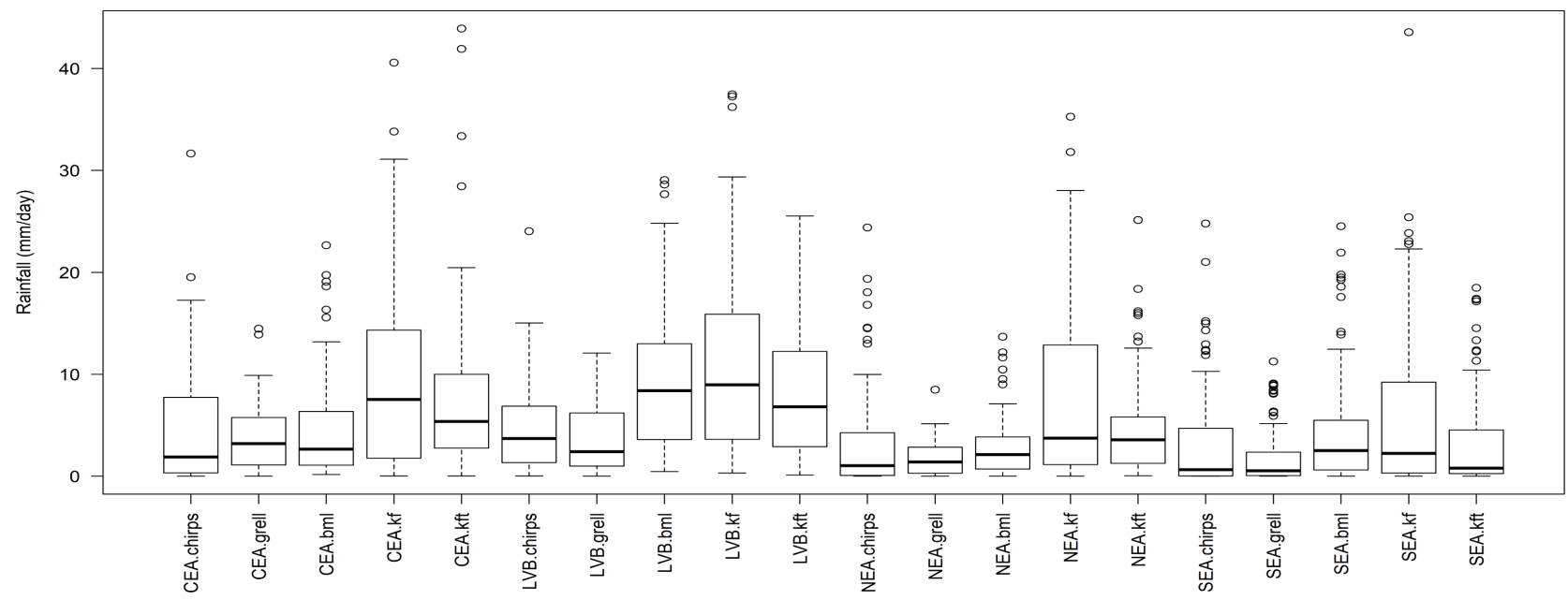

Figure 6. The box plot for daily rainfall distribution from CHIRPS, GRELL, BML, KF and KFT CPS during wet composites for (a) MAM season over NEA, SEA, LVB and CEA sub-domains. The boxes have lines at the lower, median, and upper quartile values. The whiskers are lines extending from each end of the box to 1.5 inter-quartile ranges.

BML and GRELL CPSs were closest to the observation over NEA region. Better distribution was found over SEA region in GRELL and KFT schemes.

For the OND season (Figure 7(b)), the KF and KFT schemes mean values and rainfall distribution pattern were closer to the observation, the GRELL and BML 


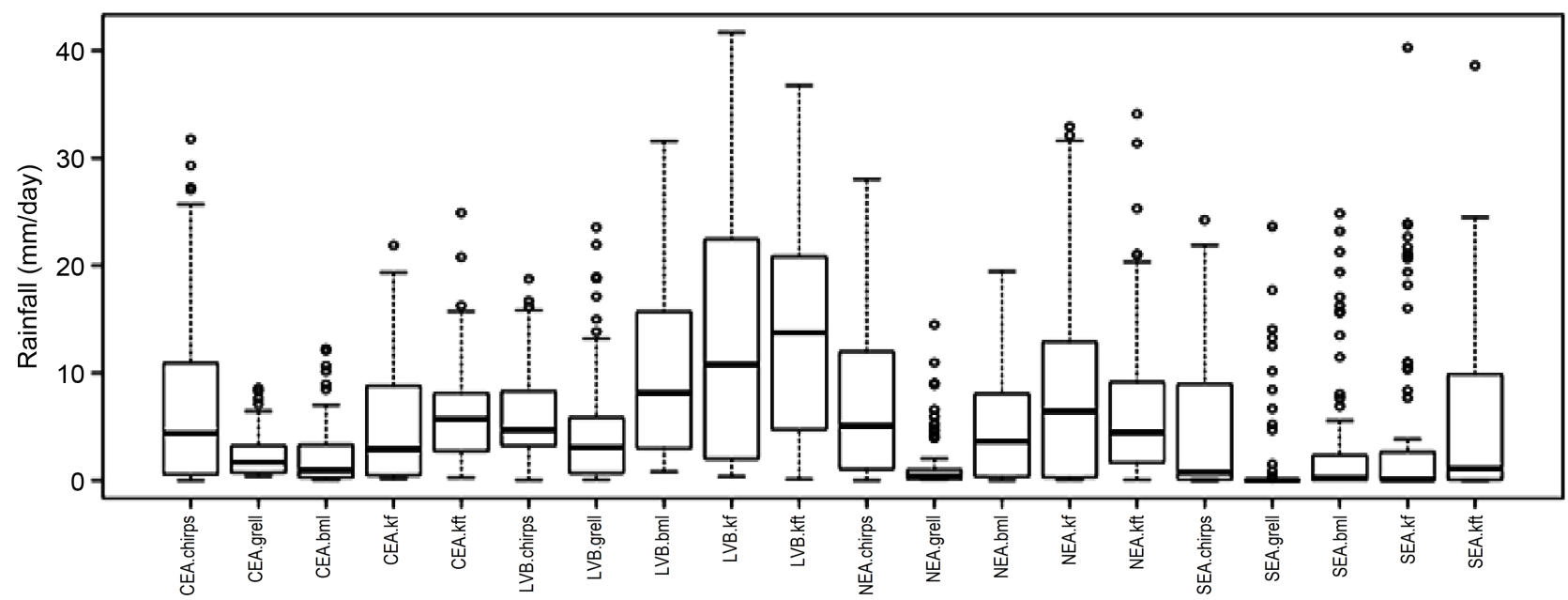

Figure 7. Same as Figure 6 but for the composite of wet years during the OND season.

CPSs underestimated the mean values over CEA region. Over LVB, only the GRELL scheme mean values were closest to the observation. Over NEA only KFT scheme was most skillful with most of the CPSs being skillful over SEA region except the KFT scheme. Fewer extreme rainfall values above $30 \mathrm{~mm} /$ day were recorded in most of the CPSs.

\subsection{The Vertically Integrated Moisture Flux}

To further provide better understanding on the rainfall characteristics simulated by the cumulus schemes, the vertically inter-grated moisture flux (VIMF) was analyzed as a proxy to rainfall. Figure 8 and Figure 9 show the moisture transport for MAM and OND rainfall seasons respectively.

During the MAM season (Figure 8), there was enhanced moisture transport into East Africa region from the southeast Indian Ocean in GRELL scheme as illustrated in Figure 8(a). For the BML, KF and KFT schemes, strong moisture transport was observed over the northeastern Indian Ocean and Arabian high regions as was illustrated in Figure 8(c), Figure 8(e) and Figure 8(g). The regions of moisture convergence were seen over parts of the Congo region, southern parts of the region and around the northern parts of Ethiopia in all the CPSs. Over the Indian Ocean, there was no convergence of moisture (divergence), a weak cyclonic circulations characterized the central parts of the Indian ocean. In the KF and KFT CPSs enhanced moisture convergence could be seen around the Congo region and the western parts of Ethiopia (Figure 8(c) and Figure 8(d)).

Divergence was over the Arabian high and the southern parts of Sudan. During the OND season (Figure 9), strong moisture transport was observed around Equatorial region from the Indian Ocean in all the CPSs (Figures 9(a)-(d)). The regions with positive biases in VIMF convergence and divergence coincided with regions of positive and negative rainfall biases (Figure 2 and Figure 3). The moisture flux bias showed enhanced VIMF being transported to the southern parts of the Indian Ocean and northern parts into western parts of the equatorial 


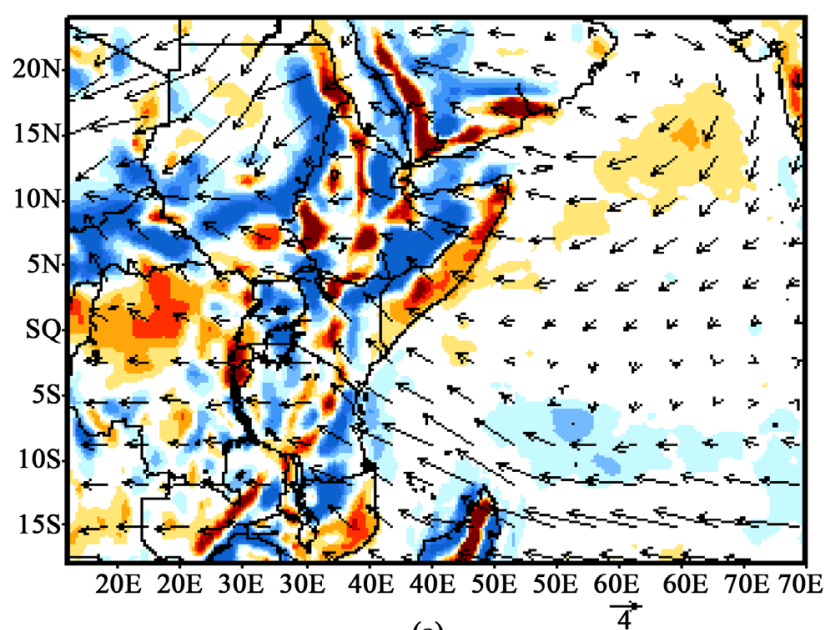

(a)

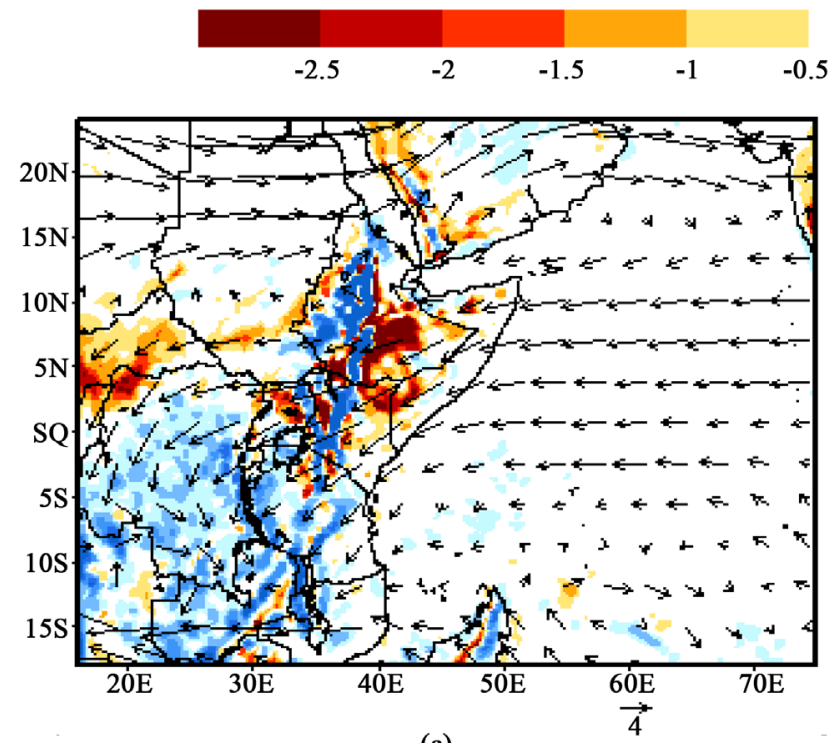

(c)
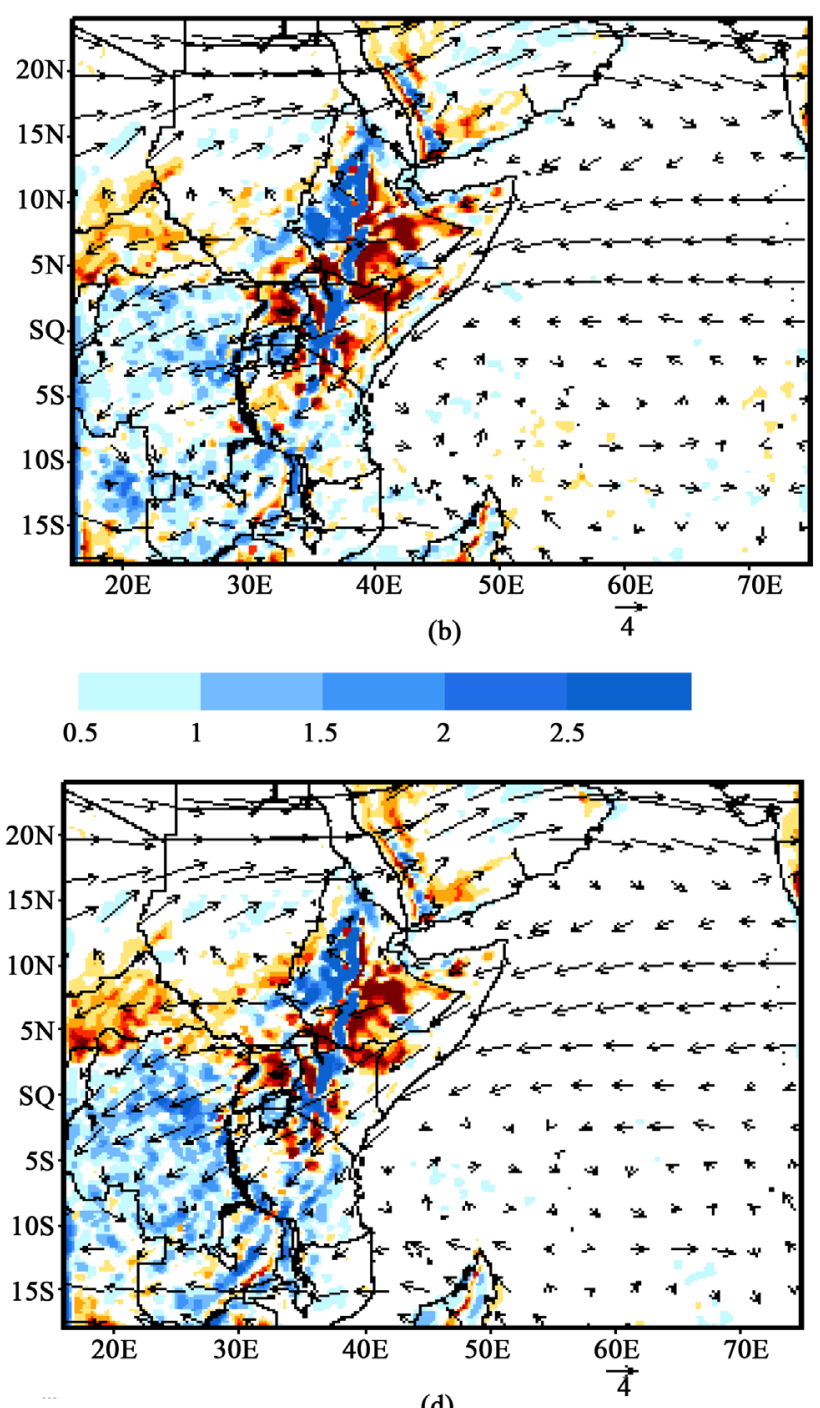

(d)

Figure 8. Spatial patterns of vertically Integrated (from 850 to $300 \mathrm{hPa}$ ) moisture convergence and divergence and the associated biases $\left(\times 10^{3}\right)$ (shaded) and moisture fluxes (arrows) from GRELL, BML, KF and KFT convective schemes during MAM wet years $(1989,1998$ and 2012). The biases were calculated with respect to ERA interim. The blue and orange shading denotes positive and negative values representing areas of moisture convergence and divergence respectively. (a) GRELL; (b) BML; (c) KF; (d) KFT.

region. This has the potential to generate wetter rainfall conditions over the same areas.

Over the Congo region, the moisture transport was away from the equatorial region, cutting the supply of moisture into the region. As had earlier been reported by [11] [54], near the tip of the horn of Africa, north easterlies are enhanced in conjunction with anomalous high pressure cells that develops over the Arabian Sea region. These northeasterly winds advect moist air toward the Ethiopian highlands and this by extension impact the East Africa rainfall regimes.

The easterly moisture transport evidently contributes to the observed rainfall characteristics over the EA region. This was corroborated by the steady easterly 


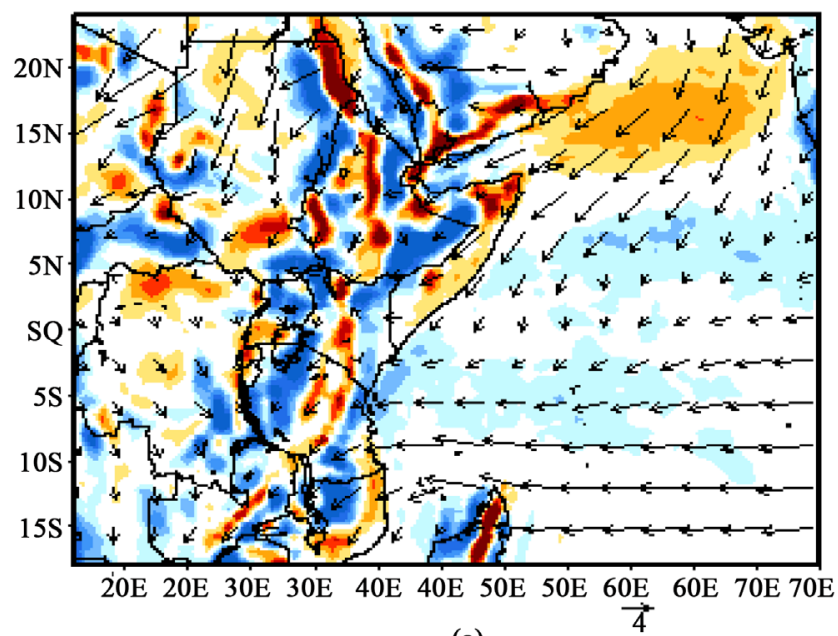

(a)

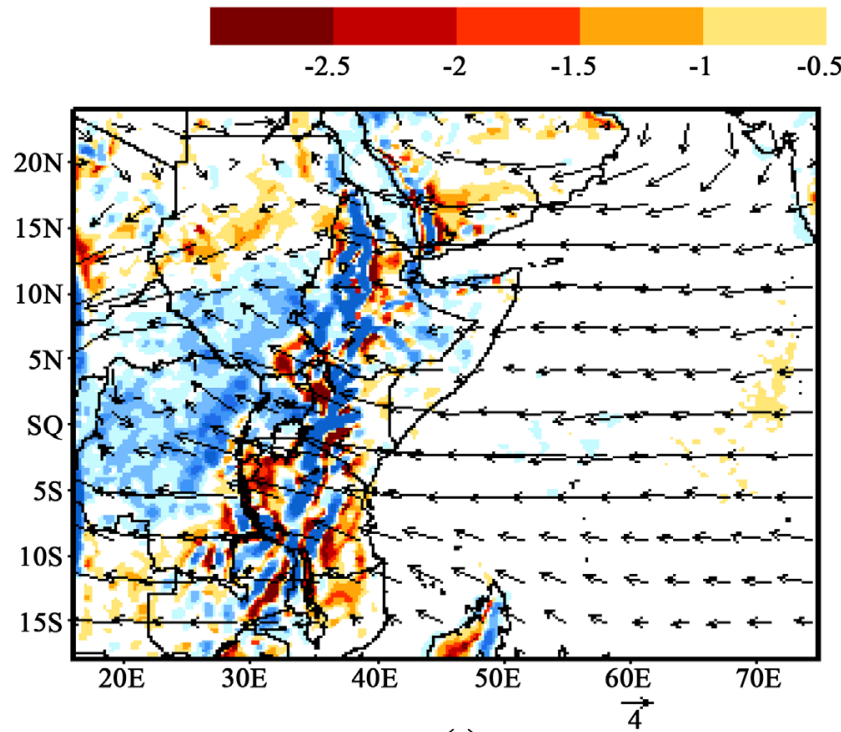

(c)

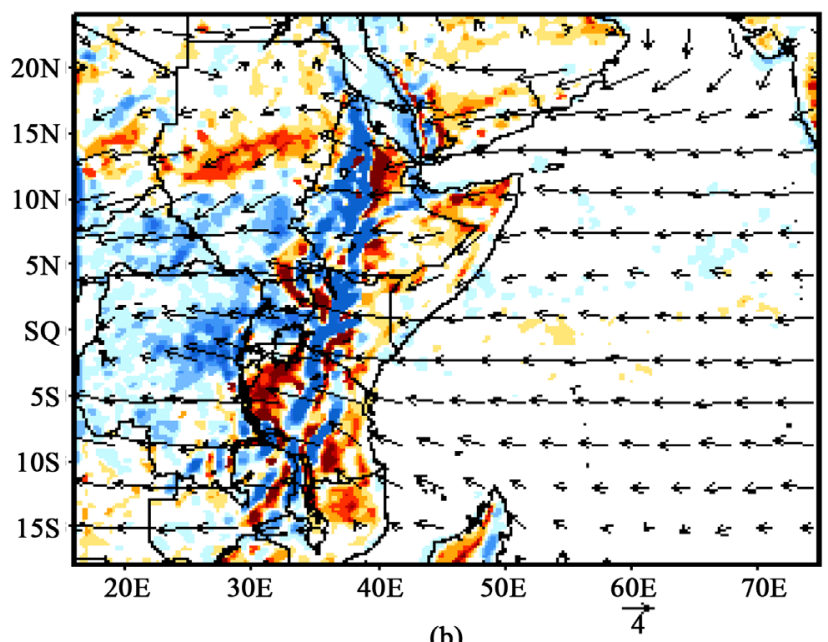

(b)
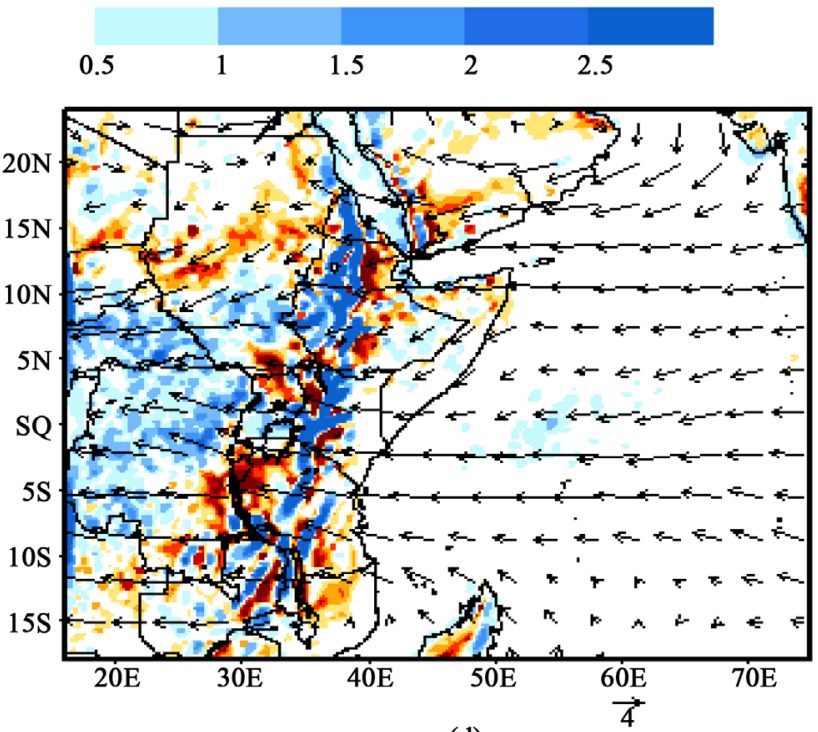

(d)

Figure 9. Same as Figure 8 but for the OND season wet years (1997, 2006 and 2015). (a) GRELL; (b) BML; (c) KF; (d) KFT.

flow and development of cyclonic activity over northern Madagascar and along the EA coasts during the OND and MAM seasons. These were best replicated in the KF and GRELL schemes. Similar findings had been reported by [55]. The easterly moisture flux over the tropical Indian Ocean has been found to contribute to moisture advection towards EA and to favor moist convective processes [27]. From the analyses of VIMF, it may be concluded that GRELL and KFT schemes reproduced moisture fluxes better than the rest of the schemes.

\section{Summary and Conclusions}

The study identified the Kain-Fritsch (KF) scheme as the most suitable scheme for rainfall simulations. Importantly, the moisture based on advection trigger function when applied to the scheme can drastically minimize the wet rainfall biases and improve on its rainfall simulation skill. Also the GRELL scheme simulated most of the rainy days fairly especially over the western parts of the re- 
gion. In terms of the error analysis, the GRELL scheme generated lower RMSE with respect to the observations than the KF scheme. The Kain-Fritsch scheme was more skilful in capturing the seasonal mean pattern with higher spatial correlations over the western parts of the region.

The KF and GRELL schemes were most skillful due to the nature of their closure assumptions. Both the schemes are based on the Langragian parcel method and thermal forcing. The BML scheme was in most cases not skillful, and did not provide consistent results. For proper utilization of the scheme, further tuning and deeper process investigation should be conducted.

The persisting too wet conditions over the Indian Ocean and Congo regions and too dry conditions over the eastern parts of Kenya weakens the reproducibility of regional climate by the schemes. The results of the study for the first time provided useful insights on the improvement of CPSs in providing more skilled rainfall prediction to effectively address regional early warning challenges and disaster risk reduction plans. The study provided new knowledge on the use of cumulus schemes over the region for modeling regional rainfall characteristics.

\section{Acknowledgements}

This research was jointly funded by the Korea Meteorological Administration Research and Development Program under Grant KMIPA2015-6130 and ICPAC-UNDP project (2.2.1a or 1.3.2a.). The computational resources for this study were provided under the PLSI program by Korea Institute of Science and Technology Information and PKNU Super-Computer Center.

\section{Conflict of Interest}

The Author declares lack of potential conflict of Interests.

\section{References}

[1] Opijah, F.J., Mutemi, J.N. and Ogallo, L.A. (2014) Application of the Ems-Wrf Model in Dekadal Rainfall Prediction over the EA Region. African Journal of the Physical Sciences, 1, 1.

[2] Kang, I.S., Jin, K., Wang, B., Lau, K.M., Shukla, J., Krishnamurthy, V., Meehl, G., et al. (2002) Intercomparison of the Climatological Variations of Asian Summer Monsoon Precipitation Simulated by 10 GCMs. Climate Dynamics, 19, 383-395. https://doi.org/10.1007/s00382-002-0245-9

[3] Huang, D.Q., Zhu, J., Zhang, Y.C. and Huang, A.N. (2013) Uncertainties on the Simulated Summer Precipitation over Eastern China from the CMIP5 Models. Journal of Geophysical Research: Atmospheres, 118, 9035-9047. https://doi.org/10.1002/jgrd.50695

[4] Giorgi, F. and Bates, G.T. (1989) The Climatological Skill of a Regional Model over Complex Terrain. Monthly Weather Review, 117, 2325-2347. https://doi.org/10.1175/1520-0493(1989)117<2325:TCSOAR>2.0.CO;2

[5] Kim, I.W., Oh, J., Woo, S. and Kripalani, R.H. (2018) Evaluation of Precipitation Extremes over the Asian Domain: Observation and Modelling Studies. Climate Dy- 
namics, 1-26. https://doi.org/10.1007/s00382-018-4193-4

[6] Dai, A. (2006) Precipitation Characteristics in Eighteen Coupled Climate Models. Journal of Climate, 19, 4605-4630. https://doi.org/10.1175/JCLI3884.1

[7] Ogwang, A.B., Chen, H., Tan, G., Ongoma, V. and Ntwali, D. (2015a) Diagnosis of East African Climate and the Circulation Mechanisms Associated with Extreme Wet and Dry Events: A Study Based on $\mathrm{RegCM}_{4}$. Arabian Journal of Geosciences, 8, 10255-10265.

[8] Ogwang, B.A., Ongoma, V., Xing, L. and Faustin, K.O. (2015b) Influence of Mascarene High and Indian Ocean Dipole on East African Extreme Weather Events. Geographica Pannonica, 19, 64-72.

[9] Pohl, B., Cre'tat, J. and Camberlin, P. (2011) Testing WRF Capability in Simulating the Atmospheric Water Cycle over Equatorial East Africa. Climate Dynamics, 37, 1357-1379. https://doi.org/10.1007/s00382-011-1024-2

[10] Anyah, R. and Semazzi, F.H.M (2006) Climate Variability over the Greater Horn of Africa Based on NCAR AGCM Ensemble. Theoretical and Applied Climatology, 86, 39-62. https://doi.org/10.1007/s00704-005-0203-7

[11] Segele, Z.T., Lance, M.L. and Lamba, P.J. (2009) Evaluation and Adaptation of a Regional Climate Model for the Horn of Africa: Rainfall Climatology and Interannual Variability. International Journal of Climatology, 29, 47-65. https://doi.org/10.1002/joc.1681

[12] Kerandi, N.M., Laux, P., Arnault, J. and Kunstmann, H. (2017) Performance of the WRF Model to Simulate the Seasonal and Interannual Variability of Hydrometeorological Variables in East Africa: A Case Study for the Tana River Basin in Kenya. Theoretical and Applied Climatology, 130, 401-418. https://doi.org/10.1007/s00704-016-1890-y

[13] Mariotti, L., Coppola, E., Sylla, M.B., Giorgi, F. and Piani, C. (2011) Regional Climate Model Simulation of Projected 21st Century Climate Change over an All-Africa Domain: Comparison Analysis of Nested and Driving Model Results. Journal of Geophysical Research: Atmospheres, 116, D15111. https://doi.org/10.1029/2010JD015068

[14] Anyah, R.O. and Semazzi, F.H.M. (2007) Variability of East African Rainfall Based on Multiyear RegCM3 Simulations. International Journal of Climatology, 27, 357-371. https://doi.org/10.1002/joc.1401

[15] Davis, N., Bowden, J., Semazzi, F.H.M., Xie, L. and Önol, B. (2009) Customization of RegCM3 Regional Climate Model for Eastern Africa and a Tropical Indian Ocean Domain. Journal of Climate, 22, 3595-3616. https://doi.org/10.1175/2009JCLI2388.1

[16] Druyan, L., Fulakeza, M.P. and Noble, E. (2009) Regional Climate Model Simulation of the AMMA Special Observing Period \#3 and the Pre-Helene Easterly Wave. Meteorology and Atmospheric Physics, 105, 191-210. https://doi.org/10.1007/s00703-009-0044-5

[17] Vogel, P., Knippertz, P., Fink, A.H., Schlueter, A. and Gneiting, T. (2018) Skill of Global Raw and Postprocessed Ensemble Predictions of Rainfall over Northern Tropical Africa.

[18] Fosser, G., Khodayar, S. and Berg, P. (2015) Benefit of Convection Permitting Climate Model Simulations in the Representation of Convective Precipitation. Climate Dynamics, 44, 45-60. https://doi.org/10.1007/s00382-014-2242-1

[19] Wang, W. and Seaman, N. (1997) A Comparison Study of Convective Parameterization Schemes in a Mesoscale Model. Monthly Weather Review, 125, 252-278. 
https://doi.org/10.1175/1520-0493(1997)125<0252:ACSOCP>2.0.CO;2

[20] Gallus, W.A. (1999) Eta Simulations of Three Extreme Precipitation Events: Sensitivity to Resolution and Convective Parameterization. Weather and Forecasting, 14, 405-426. https://doi.org/10.1175/1520-0434(1999)014<0405:ESOTEP>2.0.CO;2

[21] Leung, L.R., Qian, Y., Bian, X., Washington, W.M., Han, J. and Roads, J.O. (2004) Mid-Century Ensemble Regional Climate Change Scenarios for the Western United States. Climatic Change, 62, 75-113. https://doi.org/10.1023/B:CLIM.0000013692.50640.55

[22] Chen, L., Liang, X.Z., DeWitt, D., Samel, A.N. and Wang, J.X. (2016) Simulation of Seasonal US Precipitation and Temperature by the Nested CWRF-ECHAM System. Climate Dynamics, 46, 879-896. https://doi.org/10.1007/s00382-015-2619-9

[23] Mutemi, J.N., Ogallo, L.A., Krishnamurti, T.N., Mishra, A.K. and Kumar, T.S.V. (2007) Multimodel Based Superensemble Forecasts for Short and Medium Range NWP over Various Regions of Africa. Meteorology and Atmospheric Physics, 95, 87-113. https://doi.org/10.1007/s00703-006-0187-6

[24] Endris, H.S., Omondi, P., Jain, S., Lennard, C., Hewitson, B., Chang'a, L., Awange, J., Dosio, A., Ketiem, P., Nikulin, G., Panitz, H., Buchner, M., Stordal, F. and Tazalika, L. (2013) Assessment of the Performance of CORDEX Regional Climate Models in Simulating Eastern Africa Rainfall. Journal of Climate, 26, 8453-8475.

https://doi.org/10.1175/JCLI-D-12-00708.1

[25] Anyah, R.O., Semazzi, F.H.M. and Xie, L. (2006) Simulated Physical Mechanisms Associated with Climate Variability over Lake Victoria Basin in East Africa. Monthly Weather Review, 134, 3588-3609. https://doi.org/10.1175/MWR3266.1

[26] Ratna, S.B., Ratnam, J.V., Behera, S.K., Ratnam, J.V., Rautenbach, C.W., Lennard, J.-J., Luo, Y., Masumoto, K. and Yamagata, T. (2014) Performance Assessment of Three Convective Parameterization Schemes in WRF for Downscaling Summer Rainfall over South Africa. Climate Dynamics, 42, 2931-2953.

[27] Crétat, J., Pohl, B., Carmela, C.S., Vigaudd, N. and Yves, R. (2015) An Original Way to Evaluate Daily Rainfall Variability Simulated by a Regional Climate Model: The Case of South African Austral Summer Rainfall. International Journal of Climatology, 35, 2485-2502. https://doi.org/10.1002/joc.4155

[28] Skamarock, W.C., Klemp, J.B., Dudhia, J., Gill, D.O., Barker, D.M., Duda, M., Huang, H., Wang, W. and Powers, J.G. (2008) A Description of the Advanced Research WRF Version 3.

[29] Skamarock, W.C., Klemp, J., Dudhia, J., Gill, D.O., Barker, D.M., Wang, W. and Powers, J.G. (2005) A Description of the Advanced Research WRF Version 2.

[30] Uppala, S., Dee, D., Kobayashi, S., Berrisford, P. and Simmons, A. (2008) Towards a Climate Data Assimilation System: Status Update of ERA-Interim. ECMWF Newsletter, No. 115, 12-18.

[31] Chen, F. and Dudhia, J. (2001) Coupling an Advanced Land-Surface/Hydrology Model with the Penn State/NCAR MM5 Modeling System. Part 1: Model Description and Implementation. Monthly Weather Review, 129, 569-585. https://doi.org/10.1175/1520-0493(2001)129<0569:CAALSH >2.0.CO;2

[32] Segele, Z.T., Lance, M.L. and Aondover, A.T. (2015) Sensitivity of Horn of Africa Rainfall to Regional Sea Surface Temperature Forcing. Journal of Climate, 3, 365-390. https://doi.org/10.3390/cli3020365

[33] Giorgi, F. and Shields, C. (1999) Tests of Precipitation Parameterizations Available in Latest Version of NCAR Regional Climate Model (RegCM) over Continental 
United States. Journal of Geophysical Research, 104, 6353-6375.

https://doi.org/10.1029/98JD01164

[34] Omondi, A.P. (2010) The Teleconnections between Decadal Rainfall Variability and Global Sea Surface Temperatures and Simulation of Future Climate Scenarios over East Africa. PhD Thesis, University of Nairobi, Nairobi.

[35] Otieno, V.O. and Anyah, R.O. (2012) Effects of Land Use Changes on Climate in the Greater Horn of Africa. Climate Research, 52, 77-95. https://doi.org/10.3354/cr01050

[36] Hong, S.Y. and Lim, J.O.J. (2006) The WRF Single-Moment 6-Class Microphysics Scheme (WSM6). Journal of the Korean Meteorological Society, 42, 129-151.

[37] Hong, S.Y., Noh, Y. and Dudhia, J. (2006) A New Vertical Diffusion Package with an Explicit Treatment of Entrainment Processes. Monthly Weather Review, 134, 2318-2341. https://doi.org/10.1175/MWR3199.1

[38] Alapaty, K., Herwehe, J.A., Otte, T.L., Nolte, C.G., Bullock, O.R., Mallard, M.S., Kain, J.S. and Dudhia, J. (2012) Introducing Subgrid-Scale Cloud Feedbacks to Radiation for Regional Meteorological and Climate Modeling. Geophysical Research Letters, 39, L24809. https://doi.org/10.1029/2012GL054031

[39] Ma, L.M. and Tan, Z.M. (2009) Improving the Behavior of the Cumulus Parameterization for Tropical Cyclone Prediction: Convection Trigger. Atmospheric Research, 92, 190-211. https://doi.org/10.1016/j.atmosres.2008.09.022

[40] Kain, J.S. (2004) The Kain-Fritsch Convective Parameterization: An Update. Journal of Applied Meteorology, 43, 170-181. https://doi.org/10.1175/1520-0450(2004)043<0170:TKCPAU>2.0.CO;2

[41] Kain, J.S. and Fritsch, J.M. (1992) Role of Convective Trigger Functions in Numerical Forecasts of Mesoscale Convective Systems. Meteorology and Atmospheric Physics, 49, 93-106.

[42] Grell, G.A. and Devenyi, D. (2002) A Generalized Approach to Parameterizing Convection Combining Ensemble and Data Assimilation Techniques. Geophysical Research Letters, 29, 1-4. https://doi.org/10.1029/2002GL015311

[43] Grell, G.A. (1993) Prognostic Evaluation of Assumptions Used by Cumulus Parameterizations. Monthly Weather Review, 121, 764-787. https://doi.org/10.1175/1520-0493(1993)121<0764:PEOAUB >2.0.CO;2

[44] Berhane, F. and Zaitchik, B. (2014) Modulation of Daily Precipitation over East Africa by the Madden-Julian Oscillation. Journal of Climate, 27, 6016-6034. https://doi.org/10.1175/JCLI-D-13-00693.1

[45] Schneider, T., Smith, K.L., O’Gorman, P.A. and Walker, C.C. (2006) A Climatology of Tropospheric Zonal-Mean Water Vapor Fields and Fluxes in Isentropic Coordinates. Journal of Climate, 19, 5918-5933. https://doi.org/10.1175/JCLI3931.1

[46] Trenberth, K.E., Fasullo, J.T. and Mackaro, J. (2011) Atmospheric Moisture Transports from Ocean to Land and Global Energy Flows in Reanalyses. Journal of Climate, 24, 4907-4924. https://doi.org/10.1175/2011JCLI4171.1

[47] Newman, M., Kiladis, G.N., Weickmann, K.M., Ralph, F.M. and Sardeshmukh, P.D. (2012) Relative Contributions of Synoptic and Low-Frequency Eddies to Time-Mean Atmospheric Moisture Transport, Including the Role of Atmospheric Rivers. Journal of Climate, 25, 7341-7361. https://doi.org/10.1175/JCLI-D-11-00665.1

[48] Funk, C., Verdin, A., Michaelsen, J., Peterson, P., Pedreros, D. and Husak, G. (2015) A Global Satellite Assisted Precipitation Climatology. Earth System Science Data, 8, 
401-426. https://doi.org/10.5194/essdd-8-401-2015

[49] Pohl, B. and Cretat, J. (2014) On the Use of Nudging Techniques for Regional Climate Modeling: Application for Tropical Convection. Climate Dynamics, 43, 1693-1714. https://doi.org/10.1007/s00382-013-1994-3

[50] Pohl, B., Macron, C. and Monerie, P.A. (2017) Fewer Rainy Days and More Extreme Rainfall by the End of the Century in Southern Africa. Scientific Reports, 7, Article No. 46466. https://doi.org/10.1038/srep46466

[51] Sun, Y., Dair, A. and Solomon, S. (2006) How Often Does It Rain? Journal of Climate, 19, 916-934. https://doi.org/10.1175/JCLI3672.1

[52] Salih, A.M., Nadir, A.E., Michael, T. and Qiong, Z. (2018) Characterization of the Sahelian-Sudan Rainfall Based on Observations and Regional Climate Models. Atmospheric Research, 202, 205-218. https://doi.org/10.1016/j.atmosres.2017.12.001

[53] Philippon, N., Camberlin, P., Moron, V. and Boyard-Michea, J. (2015) Anomalously Wet and Dry Rainy Seasons in Equatorial East Africa and Associated Differences in Intra-Seasonal Characteristics. Climate Dynamics, 45, 1819-1840.

https://doi.org/10.1007/s00382-014-2436-6

[54] Chen, L., Fan, X. and Ma, Z. (2010) Approaches for Assessing Dynamically Downscale Climate. AGU Fall Meeting, San Francisco, 13-17 December 2010, Paper A21G-0181.

[55] Mlawer, E., Taubman, S., Brown, P., Iacono, M. and Clough, S. (1997) Radiative Transfer for Inhomogeneous Atmosphere: RRTM, a Validated Correlated-K Model for the Long-Wave. Journal of Geophysical Research: Atmospheres, 102, 16663-16682. https://doi.org/10.1029/97JD00237 